\title{
Christen Lyngbo - Oprør mod normerne i 1905
}

"Hvem er den høje, meget smukke blonde Herre, som med sit lysebrune store Fuldskag, sin raske Gang og sin herkuliske Skikkelse ligner en kampende Apostel, og som i disse Dage spaserer rundt paa Kjøbenhavns Gader i langflagrende Kappe, barbovedet og med Sandaler under de nogne Fodder, altid efterfulgt af en Flok Nysgerrige, som han ikke lader til at anse?"1

af Daniel Henschen, ph.d.-stipendiat, Syddansk Universitet

S ådan lød et læserbrev i Politiken den 7. november 1905. Selv i dag ville det nok være et usædvanligt syn selvom de første blomsterbørn to generationer senere gjorde sandaler til mainstream - ikke mindst i novemberkulden. Men året var 1905, og for københavnerne var den manglende hovedbekladning det mest kontroversielle: Allerede et par dage i forvejen havde Randers Amtsavis kunnet berette om fænomenet under den sigende overskrift "Uden Hat og Stok."

Politiken kunne snart løfte sløret for mandens identitet $i$ en illustreret artikel om "Den vandrende Ridder" (til højre herfor): ${ }^{3}$ Navnet var Christen Lyngbo. Maler, født i 1871 i landsbyen Vrøgum i nærheden af Oksbøl i Vestjylland. ${ }^{4}$ I dag er han nok stort set glemt uden for Varde og omegn, som var hans base og motivlandskab for billeder af får, hede og folkeliv, og her huskes han stort set kun som maler og måske som en markant personlighed i sine sidste år. Også Landsforeningen for Danske Naturister kan mindes ham som grundlægger af en af Danmarks ældste nudistpladser. Men i et par år lige efter sidste århundredeskifte

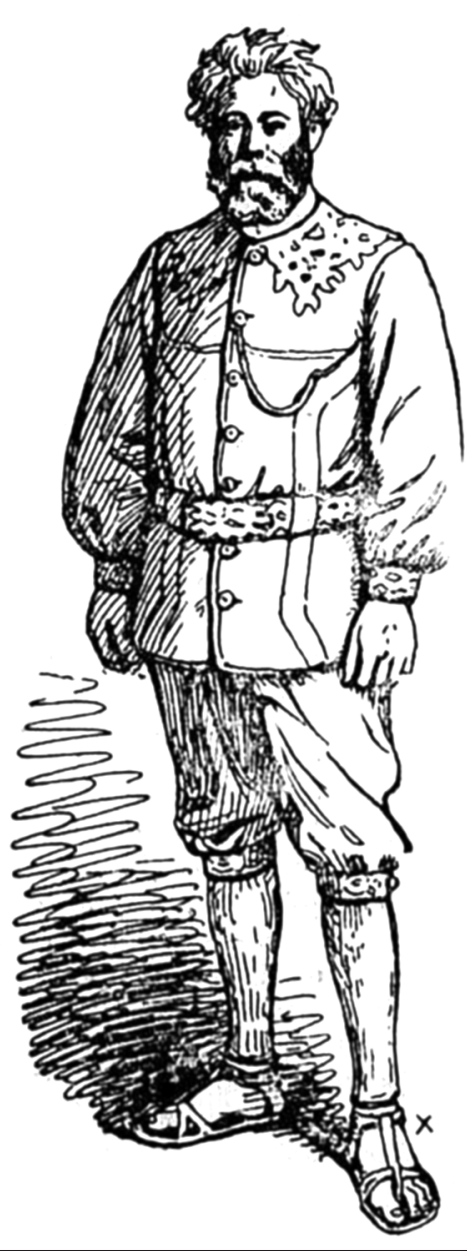




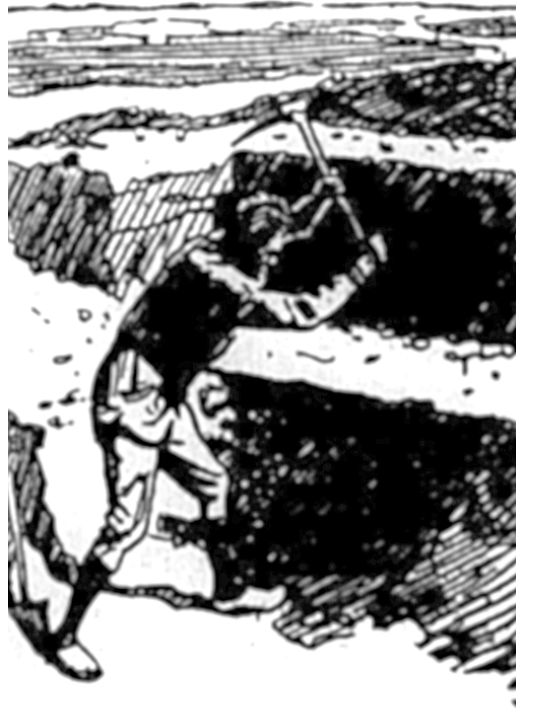

"Lyngbo arbejder paa at forbedre Hulens Udenverker." Politiken, 27.4.1906

var han en landskendt skikkelse, som en rådvild samtid havde svært ved at putte i bås. For "saa megen Opsigt [...] har vore indfødte Kunstnere dog ikke hidtil formaaet at skabe," som Randers Amtsavis skrev om Lyngbos "Apostelskikkelse." Det er den del af hans liv, som er genstand for artiklen her.

L yngbo havde gået på Kunstakademiet i 1890'erne ${ }^{6}$ (noget han senere kunne finde på at benægte ${ }^{7}$ ), men forlod i nogle år hovedstaden til fordel for den vestjyske fødeegn. Det var i årene efter denne første hjemkomst, han havde tillagt sig den klædedragt, der fik byboerne til at måbe: Ingen hat, hjemmesyet grøn kappe, tætsiddende jakke med påsyede mønstre og figurer, der blev holdt fast med et sølvspænde med dragemønstre og evt. en kraftig kxp som stok. Det var derfor, der blev råbt "Du skulle skamme dig!"8 efter ham, når han gik. Men det var ikke noget, der fik maleren til at rette ind: Året efter, at Politiken havde opdaget fænomenet, kunne aviserne skrive om, hvordan Lyngbo havde købt en høj på Vardeegnen og "vil her opslaa en Vinterbolig i en Hule, som han lader grave." Det var noget, der tilsyneladende skabte opmærksomhed uden for rigets grænser. En norsk avis spurgte således angiveligt "om der ikke blandt Norges mange originale Kunstnere skulde findes en, som kan slaa den danske Kunstmaler Lyngbo ved f. Ex. at slaa sig ned i en Tønde ligesom salig Diogenes"10 - "Mon vi skulde blive distanceret," spurgte Vestjyllands SocialDemokrat med patriotisme, ironi eller begge dele. ${ }^{11}$

Den alternative klædedragt og bolig gik i ét med en gennemført livsstil, som stak ud fra mængden: Lyngbo var eller blev i hvert fald snart naturist, tog skarpt afstand fra rygning, så besøgende journalister blev beordret til at kaste deres cigarer ud af vinduet. Og Politikens udsendte, der i foråret 1907 besøgte Lyngbos underjordiske hule, blev beværtet med linsebøf og kartoffelsalat - en "hindhedeiansk Frokost" kaldte journalisten det med tanke på samtidens vegetariske agitator, lægen Mikkel Hindhede. ${ }^{12}$ Kunstneren i hulen var altså tilsyneladende vegetar.

Og Lyngbos oprør gjaldt også ægteskab og borgerlige normer generelt. I 1908 bad "Den barhovede Maler Christen Lyngbo, som i denne Tid tiltrækker sig opmærksomhed på Strøget” Politiken annoncere, at han havde indgået ægteskab "uden kirkelig eller borgerlig Vielse" med maleren Ida Jøker. ${ }^{13}$ Og meddelelsen blev 
Christen Lyngbo i 1905. Foto i Varde lokalhistoriske arkiv.

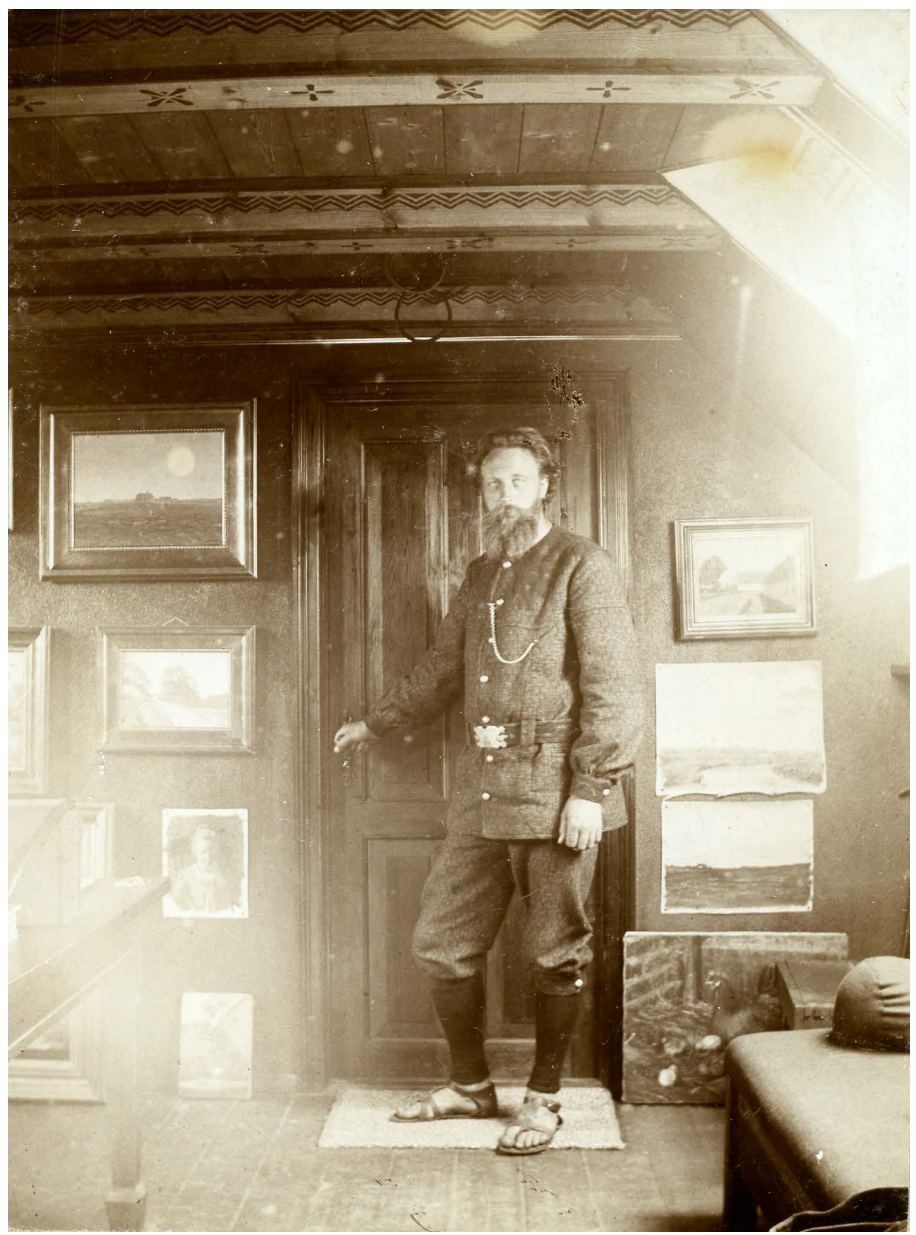

med begejstring viderebragt af en række af landets forskellige aviser. ${ }^{14}$

\section{På det alternative parnas}

Alternativ i tøj, bolig, mad og samliv og med et andet syn på menneskets forhold til natur og by. Alt sammen ting, som vi i dag forbinder med 1960'erne - eller tidligst med mellemkrigstidens alternative miljøer, som Hans Scherfig har udstillet i Idealister. ${ }^{15}$ Men faktisk var tiden lige omkring århundredeskiftet en blomstringstid for alternative bevægelser. Slutningen af 1800-tallet blev af mange set som en dekadent forfaldstid, hvor mennesket dyrkede det usunde byliv og sine egne dårlige nerver - en rolle som Herman Bang blev indbegrebet af i Danmark. Fra omkring 1890 og de næste par årtier foldede den næste generation sig i stedet ud med kropsdyrkelse og længsel efter et sundt udendørsliv. 'Vitalisme' har man senere kaldt en del af disse dynamiske strømninger, ${ }^{16}$ men perioden rummede 
også dyrkelse af orientalsk kultur og antiautoritære samfundsidealer. I disse miljøer kan man genfinde en del af Lyngbos alternative Livsstil:

Som Politiken bemærkede, var Lyngbo ikke den eneste i Danmark, der forsagede kød: Lægen Mikkel Hindhede (18621945) agiterede på samme tid for en simpel, vegetarisk kost: Kinesiske husmænd og nøjsomme havebrugere skulle være forbilledet for de forvænte europæere. ${ }^{17} \mathrm{Fa}^{\circ}$ år før havde gruppen 'Hellenerne' fejret deres somre på Refsnæs ved Kalundborg: Nøgne eller i toga havde en gruppe unge studenter og kunstnere boet sammen først i et telt og senere en selvbygget hytte. Hele sommeren malede, digtede, drak og badede de som antikkens grækere og dyrkede de idealer om den sunde sjæl i det sunde legeme, som på samme tid kom til udtryk i genoptagelsen af de olympiske lege. ${ }^{18}$

Og Lyngbos kritik af det kropsfremmede tøj og stillesiddende liv blev delt af idrætspioneren J.P. Müller (1866-1938): Året før Lyngbos gennembrud i offentligheden havde den verdenskendte kropsdyrker udsendt bogen Mit System, som i de næste år blev oversat til en lang række sprog. ${ }^{19}$ Med egne institutter i bl.a. Storbritannien udbredte Müller en krops- og bevægelsesfilosofi, som har sat et markant aftryk på gymnastik og kropssyn frem til i dag - ja, den britiske historiker Mark Singleton mener ligefrem, at Müllers tanker har været med til at forme det, man i vesten forstår som yoga. ${ }^{20}$

I Lyngbos livsførelse kunne mange af tidens teoretikere og agitatorer finde en helt spontan manifestation af deres idealer - trådt ind fra det uspolerede landliv med lige dele sund kropsfornuft og kunstneriske drømmevisioner. Det er ikke mærkeligt, at de kastede sig over ham med begejstring. Allerede få dage efter de første artikler i Politiken mødtes Lyngbo med Müller, som konkluderede, at "Lyngbos Dragt er køn og i mange Henseender praktisk" - selvom den efter hans mening nok kunne simplificeres en del. ${ }^{21} \mathrm{Og}$ det etablerede samfunds modstand skulle Lyngbo ikke bekymre sig om: "mig har Angrebene aldrig generet," lød ordene fra kropsdyrkelsens nestor. ${ }^{22}$

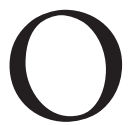
gså lægen Frode Sadolin (18661951), der som lillebror til Gunnar Sadolin - en af 'Hellenernes' kernefigurer - havde deltaget i somrene på Refsnæs, fik øje på Lyngbo. Sadolin havde omsat idealerne i sin 'mekanoterapeutiske' klinik og var foregangsmand for brugen af massage og fysioterapi. ${ }^{23}$ Han var hurtigt ude med en invitation til Lyngbo om at bidrage til den nye bog, der skulle samle hele opgøret med det stillesiddende liv: Sommerbogen, som udkom i 1906, havde forsideillustrationer af en nøgen yngling og en dansk sejlbåd. ${ }^{24}$ Så blev det ikke mere århundredeskifte og vitalisme.

Her skrev Müller om nøgenkultur ${ }^{25}$ og Sadolin selv om "Frilufts-Gymnastik,"26 mens andre artikler anbefalede cykling, boldspil og "en regelmæssig, lidt spartansk Levemåde," som det hed med det progressive å i i stedet for tidligere tiders 'aa. ${ }^{27} \mathrm{Og}$ her kunne Lyngbo folde sin kritik og sine visioner ud i kapitlet "Vore Klæder":

"Nu har vi igen den dejlige Tid, da man overalt kan trave omkring med bare Fødder. Overalt - ja gid det var så vel. Men ikke en Gang ude paa Landet kan man gå, som man har Lyst, uden at blive betragtet af mange som én der er sådan lidt 'småtosset."'28 


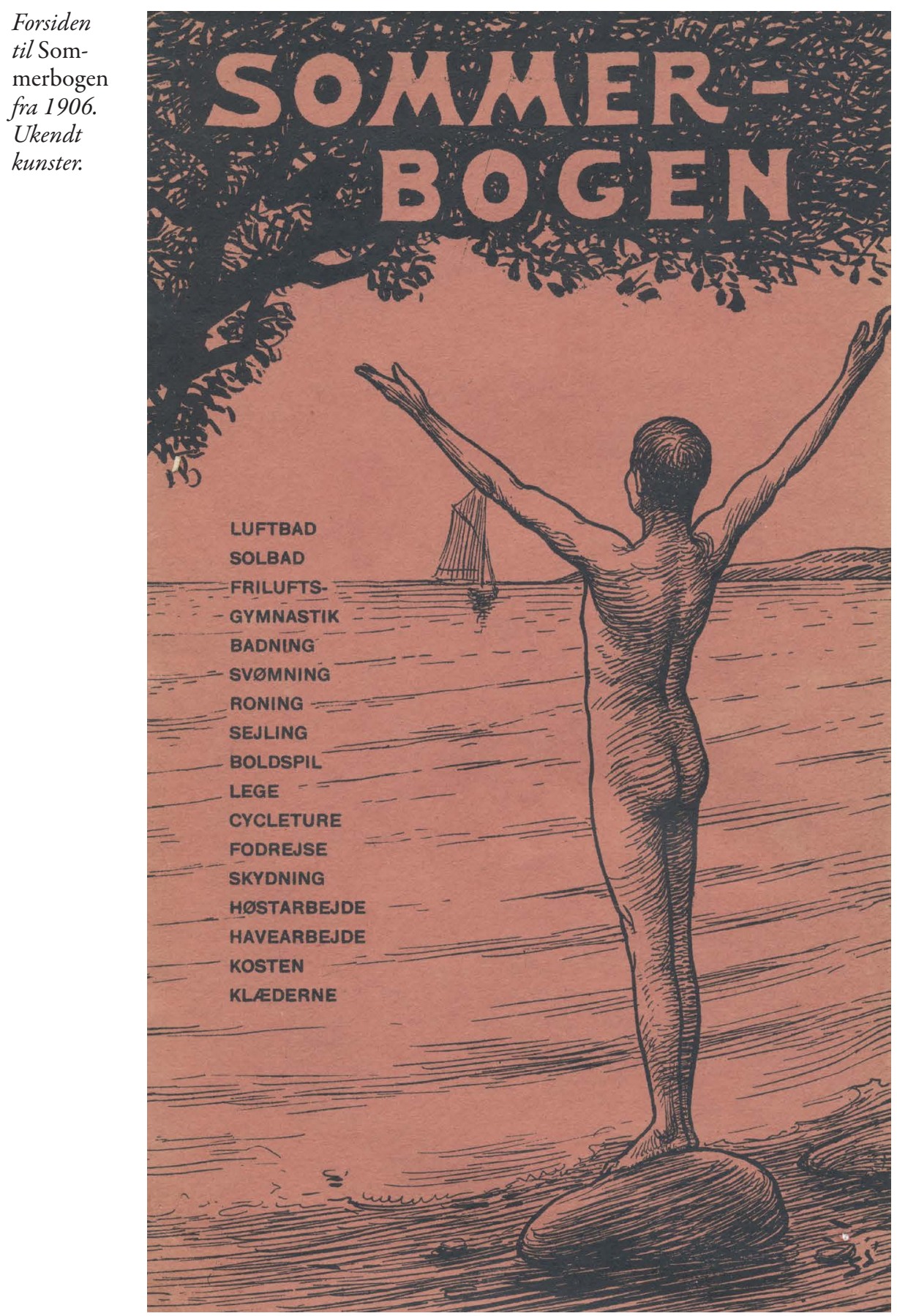


Han kunne fortælle, hvordan hans øjne var blevet bedre, hvordan han var holdt op med at tabe håret og ikke længere havde hovedpine - alt sammen efter at have droppet hatten. ${ }^{29}$ Lyngbo var dog godt klar over, at man næppe, "navnlig ikke inde i Byerne vil gå så radikalt til Værks, at gå barhovedet." ${ }^{30}$ Men så kunne man måske bedre få has på den høje hat og "det særlig uskønne i Mandsdragten"31 og i stedet gå i tøj, der passede til kroppen - "Vi er jo alle forskellige af Udseende, og derfor burde Påklædningen rette sig." 32 Man skulle finde noget af "den Kraft og Spændstighed, som man betages af ved at se et nøgent velskabt Legeme." ${ }^{33}$ Og efter en hyldest til de gamle folkedragter afsluttede maleren artiklen med en detaljeret anvisning på at fremstille de sandaler, han selv gik med hele året. ${ }^{34}$

Lyngbo var altså blevet anerkendt af den alternative bevægelses inderkreds, og i de næste par år blev han løbende omtalt i pressen over hele landet som 'reformmand' - datidens betegnelse for idealister, der arbejdede på at ændre samfundet. Og hans livsstil og arbejde som maler gik i ét i pressens billede. Som det for eksempel hed i Fyens Stiftstidende i 1908:

"Maleren Lyngbo, der har opholdt sig i Odense et Par Maaneder, og som har tiltrukket sig almindelig Opmærksomhed ved sin 'Reformdragt,' udstiller i de kommende Dage ca. 50 Malerier paa Industripalæet."35

\section{Tilbage til Vestjylland}

Men tilknytningen til det alternative parnas varede ikke længe, i hvert fald ikke på det officielle plan. Lyngbo var helt tydeligt ikke interesseret $\mathrm{i}$ at grundlægge en bevægelse og måske ikke engang $i$ at være en del af en - hvor broget og løs den så end var. Og allerede efter et par år måtte nogle af hans tidligere prominente støtter resignere: "Hans Idealer ere imidlertid mere prægede af Kunstsans end af Sans for det sunde og praktiske," klagede J.P. Müller kun lidt under to år efter udgivelsen af Sommerbogen. Og Frode Sadolin måtte samtidig konstatere, at maleren fra Vestjylland var "lidet energisk og lidet agitatorisk." ${ }^{36}$

Den landsdækkende bevægelse, som Lyngbo ifølge flere aviser påtænkte at grundlægge som led i et "Korstog mod den moderne Klædedragt," fik da heller ikke mange tilhængere. Det lød ellers betagende i pressen: "Han begynder $\mathrm{i}$ København [...] og allevegne danner han smaa Foreninger: 'Fremtidens Klædedragt.". 37

På samme tid blev Lyngbos besøg $\mathrm{i}$ Hovedstaden mere og mere spredte, men i Vestjylland fortsatte han sit liv som før: Fra 1908 boede han og Ida Jøker et par år i, hvad Vestjyllands Social-Demokrat kaldte "et gammelt utæt Blokhus" på den ellers ubeboede halvø Skallingen i Vadehavet. ${ }^{38}$ Og senere fandt han og hans næste kone, Heda Jacobsen, en blivende bolig på heden ved Varde i et hus, som Lyngbo fik opført og gav navnet Mythamunin - det betyder angiveligt 'Midhavsmundingen.' I det hedelandskab, han opkøbte udenom, malede han ofte nøgen, plantede træer som æstetiske dekorationer af landskabet og havde forskellige mere eller mindre realistiske planer, bl.a. om en park med dinosaurfigurer i 'naturlig' størrelse. ${ }^{39}$

Dermed fulgte hans liv den bane, som mange af 1960'ernes hippier senere foretog: fra storbyernes alternative miljøer og ud på landet. Selv hvad angår det mytologiske drømmeperspektiv var de i hælene på Lyngbo: det oldnordiske Mythamunin 
rimer på navne som teatergruppen Solvognen og rockgruppen Bifrost.

Hvad hans tidligere støtter i storbyen måske overså eller ikke var så glade for var, at Lyngbo på dette område var mere radikal end lederne af de forskellige reformbevægelser: Sadolin, Müller, Hindhede og de personer i de højborgerlige kredse, der dyrkede indiske tænkere, var på godt og ondt en del af det moderne byliv, de var så kritiske overfor. Lyngbo realiserede derimod sin kritik: Når Frode Sadolin og 'hellenerne' havde aflagt togaen om efteråret, var det til fordel for lune københavnske lejligheder - ikke for at flytte ind i en jordhule.

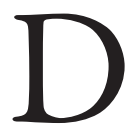
er fandtes dog andre, der som Lyngbo udlevede idealerne skønt i mindre grad i Danmark: I Rusland gik den gamle godsejer Tolstoj rundt, klædt som bonde. Men Lyngbos nærmeste åndsfæller fandtes nok i den koloni, der havde etableret sig på det lille schweiziske bjerg med det symbolske navn Monte Verità - 'Sandhedens bjerg.' Fra 1900 og nogle år frem, altså samtidig med Lyngbo, vendte indbyggerne samtiden ryggen: Som barhovede vegetarer i selvsyet tøj dannede de par efter kærlighed, digtede og praktiserede et andet samfund. ${ }^{40} \mathrm{Her}$ ville Christen Lyngbo have kunnet gå lige ind, uden at nogen ville løfte et øjenbryn. I dokumentarfilmen Freak Out fra 2014 bliver denne gruppe set som direkte forløbere for den senere beatnik- og hippiebevægelse. ${ }^{41}$

Både Lyngbo og Monte Verità-folkene praktiserede selv alle dele af deres idealer. Og de gjorde det ligesom Tolstoj ved at gøre deres eget liv og 'projektet' til en og samme ting og ved at tage fysisk afsked med det byliv og de dele af moderniteten, de var skeptiske overfor - selv ikke de officielle medier, bøger og aviser var relevante for dem. De havde ikke ambitioner om at råbe samfundet op med andet end deres egen livsform.

Dermed står de i modsætning til mange af de andre utopiske samfundsbevægelser før og siden (for eksempel den marxistiske). Deres ideal var ikke at diktere den rette lære for samtiden og udstikke programmer, som folk skulle følge i retning af ét jordisk paradis. I stedet handlede det om individuelle opgør med (dele af) de bestående rammer og om muligheden for selv at tilrettelægge sit liv. ${ }^{42}$ I en periode, hvor kloden med stormskridt blev mere og mere ensartet, hvor modernisering og imperialisme førte til centralisering af samfundslivet og kulturen, var dette udlevede opgør i sig selv ligeså radikalt som de utopiske tanker, de havde.

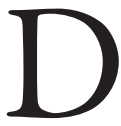
et er måske også den ramme, man skal se det $\mathrm{i}$, når Lyngbo over for forbløffede journalister udkastede store planer, som tilsyneladende ikke blev fuldført: For en landsdækkende forening til reform af klædedragten, for diverse agitationsbøger og den nævnte dinosaurpark uden for Varde. Eller når han valgte at annoncere et papirløst forhold i en stor avis. Var det ikke provokationer og happenings i sig selv, længe før Fluxus tog den praksis op?

Og Lyngbos kunst: Den bestod af billeder af natur og almindelige mennesker, landarbejdere og håndværkere, og den går dermed tilsyneladende dårligt i spænd med hans radikale liv. Men her er det igen oplagt at drage en parallel til 1960'ernes og 1970'ernes ungdomskultur: Også Lyngbo-generationens børnebørn vendte 


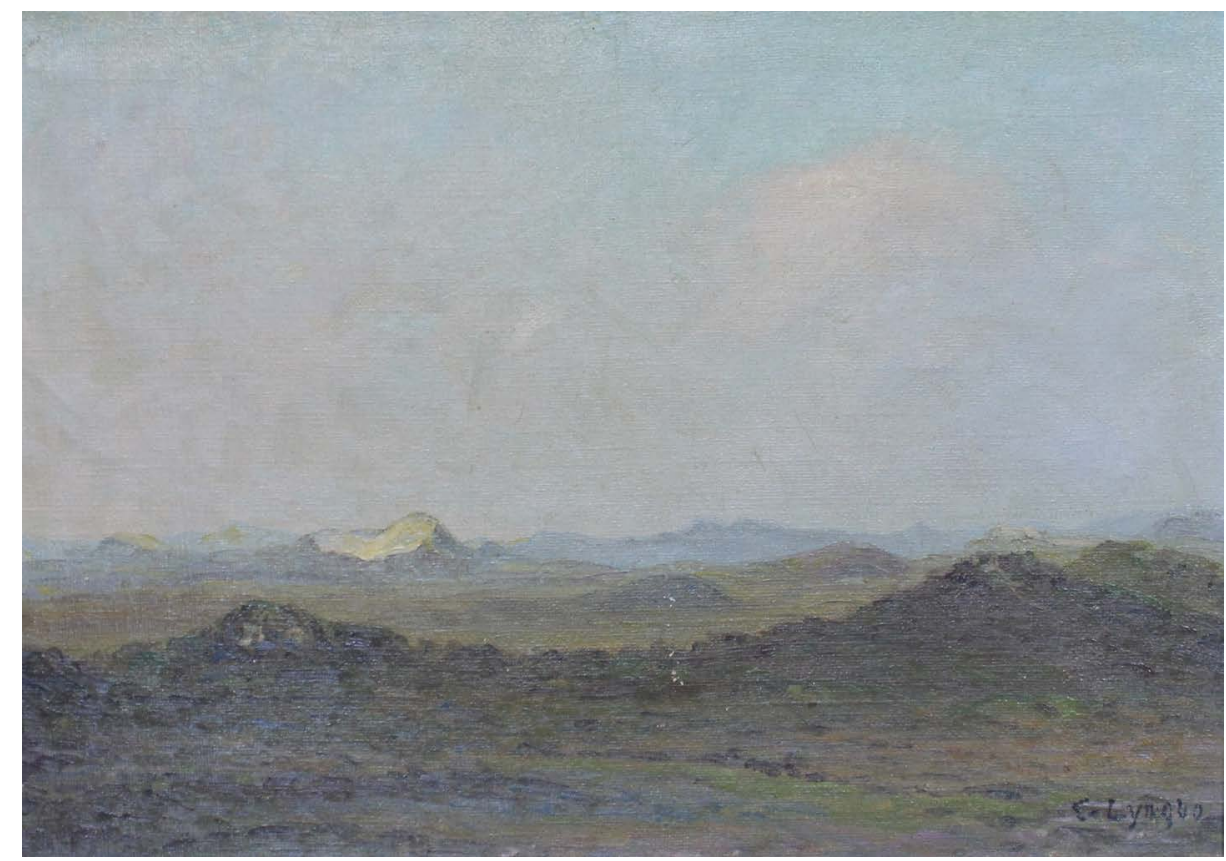

Christen Lyngbo: Hedelandskab. Uden år, privateje.

sig nemlig på samme måde æstetisk mod fortiden. Her fandt de jugendstilen som et organisk og legende alternativ til den formelle og dogmatiske modernisme. For Lyngbo var det blot en anden tidligere stil, der var mest nærliggende. De oprør inden for malerkunsten, som hans egen og den følgende generation stod for, var efter hans mening bare former og farver, der fjernede sig fra virkeligheden: I stedet holdt han fast i den naturalisme, som han selv var uddannet i på Kunstakademiet af malere som Otto Bache og Frederik Vermehren. Den var det umiddelbare medium for de lokale verdener, det naturlige og selvgroede i omgivelserne og menneskene. Det er arven fra guldalderen. Nogle af Lyngbos malerier viser solbeskinnede landskaber og kunne være illustrationer til idealerne fra Sommerbogen. Andre har et næsten radikalt antiromantisk syn på det sete; der er dis, mudder og mørke farver - samme håndfaste drøm, som at bo midt $i$ en hule i hedejorden gennem en gusten dansk vinter. Det blev Lyngbos stil gennem hele livet.

$\mathrm{L}$ igesom hans nok ubekendte åndsfæller på Monte Verità forsvandt fra bjerget i årene efter Første Verdenskrig, ${ }^{43}$ gled også Lyngbo ud af storbypressens lys, men han opgav ikke sin utopi af den grund - han var ikke blevet 'borgerlig,' som man senere ville sige. Når mellemkrigstidens journalister en gang imellem fandt vej til hans hus, handlede det altid om hans billeder, og dem havde de svært ved at passe ind i det liv, de samtidig kunne iagttage hos den ældre kunstner: "Hørte jeg rigtigt?" er en karakteristisk 
bemærkning, når Lyngbo midt imellem de forventelige betragtninger over vejr, klima og landlivets behagelighed, fortalte hvordan han malede nøgen på heden eller havde haft planer om en naturpark med dinosaurer sammesteds. ${ }^{44}$

Først i 1950'erne fik den brede offentlighed igen for alvor interesse for Lyngbos særlige livsstil: Nu blev han kendt som verdens ældste nudist ${ }^{45}$ og som manden, der forærede et kæmpe hedeareal til fredning, men fortrød det, da staten anlagde stier; ${ }^{46}$ eller som den nogle-oghalvfems-årige, som på egen hånd rejste til Middelhavet og Nordafrika ${ }^{47}$ og som 80-årig cyklede 22 kilometer i snevejr for at nå frem til et møde. ${ }^{48} \mathrm{Og}$ der opstod myter om, at Tandlægehøjskolen skulle have bedt om en kopi af den 88-årige malers fejlfrie tænder. ${ }^{49}$ Som kunstner kulminerede hans anerkendelse, da Varde Museum opførte en helt ny tilbygning til de billeder, han donerede i begyndelsen af 1960'erne - siden er Lyngbos plads som byens store maler dog veget for den visuelt mere eksperimenterende Otto Frello.

Årene som landskendt 'blomsterbarn før sin tid' blev glemt og reelt ikke omtalt siden - højest $\mathrm{i}$ indirekte vendinger - hverken i interview eller i de par mindre skrifter, der er udkommet om hans kunst. ${ }^{50}$ Selv kendte jeg til Lyngbo og hans malerier igennem familien, da jeg begyndte at interessere mig forskningsmæssigt for det, jeg kalder den 'decentrale orientering,' i kultur og samfund i årtierne omkring sidste århundredskifte: De strømninger, der som folkene på Monte Verità i voksende tal begyndte at dyrke modsætningen til den centralt vedtagne viden, magt og samfundsorganisering - hvad enten de fandt deres idealer i landbefolkninger, i ekskluderede traditioner, i koloniernes kulturer eller i andre måder at belægge sandheden på. Jeg havde ikke ventet at finde Lyngbo i dét selskab, men en tilfældig søgning på hans navn i Mediastream bragte mig lige ind i fascinationen af den barhovede skikkelse i de københavnske gader, og nye søgninger og krydstjek i bøger og tidsskrifter foldede den historie ud, der er gengivet for oven. ${ }^{51}$ Det skyldes ikke mindst de muligheder, som digitaliseringen af danske aviser har åbnet: Gennem Mediastream får man på få timer adgang til datidens dækning af ham; et arbejde, som ellers ville tage måneders minutiøs gennemlæsning.

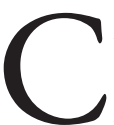
hristen Lyngbo døde i 1968 det år, der i eftertidens bevidsthed kom til at symbolisere nogle af de idealer, han havde levet med i det meste af et langt liv. 


\section{Noter}

1 “Dag til Dag," i Politiken 7.11.1905, s. 3.

2 "Uden Hat og Stok," i Randers Amtsavis 3.11.1905, s. 1.

3 "Den vandrende Ridder," i Politiken 11.11.1905, s. 6 .

4 Artikel om Lyngbo i Weilbachs kunstnerleksikon.

5 "Uden Hat og Stok" i Randers Amtsavis 3.11.1905, s. 1 .

6 Lyngbo i Weilbachs kunstnerleksikon.

7 Det gjorde han for eksempel i et interview med Jyllands Posten i 1962: “Jeg var malersvend i otte aar. Jo, jeg er faglært maler, men kom aldrig paa akademiet." "Ung mand på 91 flyver til De kanariske Øer," i Jyllands Posten 15.11.1962, s. 26), mens han to år tidligere til samme avis havde fortalt om sin tid på Kunstakademiet under Frederik Vehrmehren og Frants Henningsen ("Som Barn drømte jeg om at bo i en Ørken," i Jyllands Posten 13.3.1960, s. 14).

8 "J.P. Müller om 'Den vandrende Ridder" i Politiken 13.11.1905, s. 4.

9 Eks. "En Hulebeboer" i Aalborg Stiftstidende 12.10.1906, s. 12.

10 "De norske Nordmænd" i Vestjyllands Social-Demokrat 15.10.1906, s. 3.

11 Ibid.

12 "Lyngbo - I Reformatorens Hjem" i Politiken 27.4.1907, s. 6.

13 Politiken 10.4.1908, s. 3 (fremhævelse i originalen).

14 Eks "Vrang og ret" i Nestved Tidende 14.4.1908, s. 3; “Ægteskab” i LollandFalsters Tidende 10.4.1908, s. 2; "At han tør!" i Holstebro Avis 14.4.1908, s. 2.

15 Hans Scherfig: Idealister, 1945.

16 Sven Halse har skrevet en overordnet indføring i begrebet med udgangspunkt i den danske situation: Sven Halse: "Vitalisme - fænomen og begreb” i Kritik 171, 2004, s. 1-7.

17 Se f.eks. Mikkel Hindhede: Asketpensionatet i Jonstrup. Beretninger fra
M. Hindhedes Kontor for Ernæringsundersøgelser, 1927, s 25.

18 Om Hellenerne se for eksempel: Ole Nørlyng: "Skønheden og Sundheden," Henrik Wivel (red.): Drømmetid, 2004 og Alf Yde: "Hellenerne på Refsnæs," Jul i Kalundborg 1971.

19 "J.P. Muller" i Dansk Biografisk Leksikon.

20 Mark Singleton: Yoga Body: The Origins of Modern Posture Practice. Oxford 2010, s. 118.

21 “J.P. Müller om 'Den vandrende Ridder"” $\mathrm{i}$ Politiken 13.11.1905, s. 4.

22 Ibid.

23 Frode Sadolin i Dansk Biografisk Leksikon.

24 Frode Sadolin (red.): Sommerbogen. 1906.

25 J.P. Müller: "Luftbade og Solbade," Frode Sadolin (red.): Sommerbogen. 1906.

26 Frode Sadolin om "Frilufts-Gymnastik," samme (red.): Sommerbogen. 1906.

27 Carl Lorenzen: "Vor Kost," Frode Sadolin (red.): Sommerbogen. 1906, s. 116.

28 Christen Lyngbo: "Vore Klæder," Frode Sadolin (red.): Sommerbogen. 1906, s. 117.

29 Ibid., s. 118-119.

30 Ibid., s. 119.

31 Ibid., s. 122.

32 Ibid., s. 118.

33 Ibid., s. 122.

34 Ibid., s. 123-124.

35 "En Udstilling af Malerier" i Fyens Stiftstidende 11.7.1908, s. 7.

36 Eks. "Med bare Ben og uden Hat?" i Lolland-Falsters Tidende 18.12.1907, s. 1.

37 Ibid.

38 "Kunstmaler Lyngbo" i Vestjyllands SocialDemokrat 25.4.1908, s. 2.

39 Ifølge et senere interview ("Maleren der tog Navn efter den brune Lyng" i Berlingske Tidende 4.2.1951, s. 7).

40 Robert Landmann: Ascona, Monte Verità: auf der Suche nach dem Paradies. Zürich 1973.

41 Freak out. Instruktør Carl Javér. Det Danske Filminstitut. ÅRSTAL? 
42 Det gælder dele af Monte Verità-bevægelsen; andre var dog mere 'traditionelle' politiske og kulturelle aktivister.

43 Landmann 1973, s. $122 \mathrm{ff}$.

44 Et af de ældste interviews er Harry Sonnes artikel "En vestjysk Maler" fra Illustreret Tidende 1916, men der findes en del længere interviews med Lyngbo, særligt fra hans senere år, for eksempel: "Hedens og klitternes maler fortæller" i Jul i Vestjylland 1937, s. 25-27; "Maleren der tog Navn efter den brune Lyng" i Berlingske Tidende 4.2.1951, s. 7; "Lyngens Maler fylder 80" i Vestkysten 16.6.1951; "Kunstmaler Christen Lyngbo, Henne runder sin 90 årsdag” i Vestjyden 17.6.1961.
45 "Han er antagelig verdens ældste nudist..." i Vestjysk Aktuelt 17.6.1966, s. 14.

46 "Gav staten en million - og fortrød det igen" i Vendsyssel Tidende 27.8.1964.

47 "Ung mand på 91 flyver til De kanariske Øer," i Jyllands Posten 15.11.1962, s. 26.

48 "80-aarig cyklede 22 Kilometer til Møde" i Aarhuus Stiftstidende 11.2.1952, s. 4.

49 "Et flot gebis" i Folkebladet Sydjylland 22.8.1960, s. 2.

50 Den vigtigste er Peder Friis: Maleren Chr. Lyngbos vestjyske billeder i udvalg. Historisk Samfund for Ribe Amts småskrifter, 2, 1958.

51 Dagbladet Politiken er ikke i Mediastream, men jeg har brugt andre avisers referencer til Politiken-artikler til at finde disse på traditionel vis. 